\title{
W J McGEE, GEOLOGIST, ANTHROPOLOGIST, HYDROLOGIST.
}

BY CHARLES KEYES.

With the recent passing of our fellow eitizen Iowa mourns for her most distinguished scientist, the Nation loses a renowned personage and public official, and the World laments the extinguishment of one of her rarer species-the philosophical naturalist. W J McGee was almost the last of that famous coterie of American scientific men who especially made noteworthy the closing decades of the last century and to whom the title of naturalist was peculiarly and happily fitted.

In the ever widening circles of modern science and the concomitant ever narrowing vista of nature which the investigator of today in his outlook must face, the removal of one who in name and fame has left the stamp of his genius in more than a single field of knowledge occasions a conspicuous void. When we pass his varied activities in review and eliminate for the moment all else but the salient features in order to more clearly grasp their proper purport and to appreciate more fully their true position in the general scheme, our admiration for his abilities is the more enhanced and our feeling of loss is the keener.

W J McGee was born April 17, 1853, near Farley, in Dubuque county, Iowa. He died in Washington, D. C., September 4, 1912. At the time of his demise he was, therefore, in his sixtieth year. Although during much of his lifetime our Iowan was away from his native State he never lost either his citizenship therein or his keen interest in everything which conduced to her welfare. His parents were James and Martha (Anderson) McGee; the father being a native of Ireland and the mother a Kentuckian. 


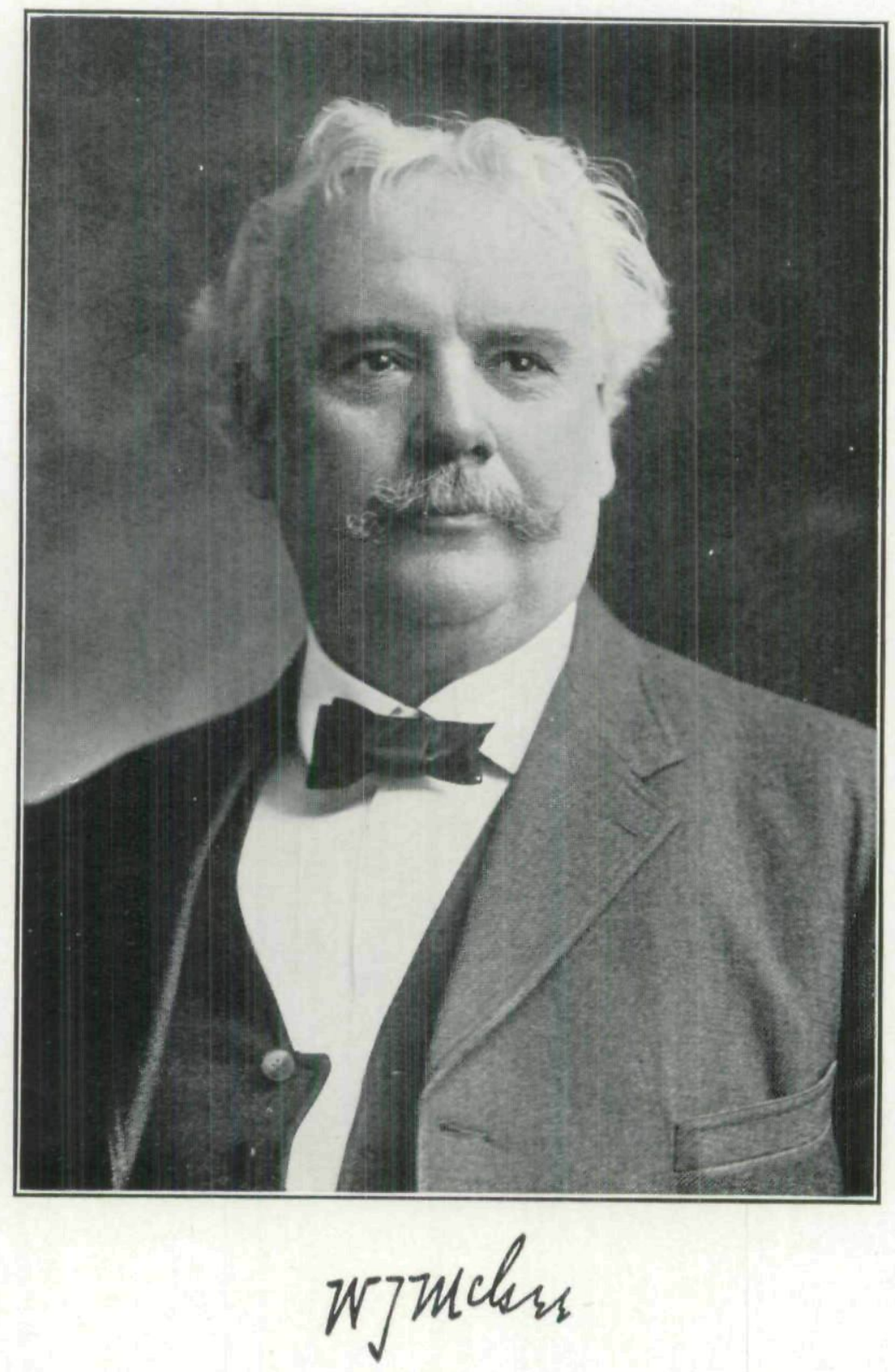


McGee's youth was spent mainly on a Dubuque County farm. Although his educational opportunities were necessarily quite limited, his inordinate thirst for knowledge enabled him, with some assistance, to acquire a fair grasp of Latin, mathematies, surveying and astronomy. His faculty of mathematical reasoning gave decided color to some of his later philosophical speculations.

The fortunes of his birth not having afforded him either the means or the chance to carry on immediately any chosen line of professional labor that his mathematical inclination dictated, young McGee was obliged to turn his energies for the time in other directions. At the age of twenty he began reading law and for two or three years he practiced in the justice courts. His many-sided mind then turned him towards the manufacturing of agricultural implements, a number of inventions and patents standing to his credit. For several years, but with constantly diminishing interest, he followed this vocation.

In the meanwhile McGee became deeply interested in the subjects of geology and archeology; and he was soon out in the fields and valleys delving into the secrets of the rocks. During four years he devoted the greater part of his time to the study of the geologic features of the northeastern portion of Iowa, the final results of which appeared a decade later in a sumptuous monograph ${ }^{1}$ published by the Federal government. These were fruitful years for McGee and the effects of their influence are apparent in all his subsequent writings. During the latter part of this period his first important papers were published in the scientific journals.

In 1881 came the opportunity for wider application of his recently acquired knowledge on the geological characteristics of his native State. Through the influence of the late Senator Allison, whose home was in Dubuque, McGee was appointed agent of the United States Census Bureau, with a commission to work up the Iowa building stones. Into this work he entered with zest and in the spring and summer of the year mentioned accomplished a prodigious amount of investigation.

111th Annual Report U. S. G. Survey, 1889-90. 
Thus he was enabled to extend his geologic studies over every county of the State. The direct results of this extended inquiry are contained in a large, lucid and very creditable report $^{2}$ published by the Government.

It was at this time that I first eame in contact with MeGee. This was the beginning of a long, close and happy friendship which was only interrupted recently by the hand of death. I well recall that initial meeting. It was in the Devil's gap, a wild, dark spot north of Des Moines. He and Prof. R. Ellsworth Call, who was at that time residing in the eapital eity, had been tramping all day over the surrounding country studying the loess and the glacial drift sections, and had finally come up to an unusually fine and extensive exposure which had been recently opened up in a road-cutting. There they found Uly Grant ${ }^{3}$ and me busily extracting molluscan shells from the loams. We had already collected a large quantity of exceptionally fine specimens over which both geologists at once went into ecstasies. At that time Grant and I were kiddies preparing for college; and among other things we had been devoting a good deal of extra time to Greek and Latin. We were also mightily interested in natural history and had been putting the dead languages to great practical use. Through the aid of Professor Call we had learned to know all the loess fossils and to eall them familiarly by their long seientific names. When the two school boys began innocently to rattle off glibly all the numerous Latin titles of the shells, MeGee was visibly affected for he had just finished relating to us something of his own prowess in the ancient languages, but, as we afterwards discovered, he did not know the name of a single shell. A score of years after, at a geological gathering, he told, with some embellishments of course, the story of that meeting and how it had greatly disconcerted him and for the time being deeply wounded his pride.

${ }^{2}$ U. S. 10 th Census, v. 10, p. 256.

aDr. Ulysses Sherman Grant, now one of the most distinguished scientists of this country, at the present time occupies the chair of geology in Northwestern University. He was a Des Moines boy. 
The work on the Tenth Census led to the calling of McGee to Washington and to his attachment to the corps of the United States Geological Survey. For a period of ten years he held this post, most of the time as chief of one of the important divisions of the Survey. It was the first of many responsible commissions which he held in the service of the Government.

McGee's first geological work for the Governent was in the deserts of Nevada. After assuming charge of the Potomac Division of the Survey his efforts were largely confined to the Atlantic border. In spite of a mountain of administrative routine, the volume of which rapidly grew as the years went by, MeGee was able to find time to visit many parts of the national domain, besides superintending the work of others in these fields. Although somewhat technical in statement the following appear to be the principal scientific achievements of our Iowan during this remarkably productive decade: The demonstration of the glacial origin of the loess in northeastern Iowa; the elucidation of certain principles of glacial action; the discrimination and elassification of a wide variety of topographic forms resulting both from iceaction and water-action; the development of the "law of land profiles," the law of varigradation," and the "law of foothills;" reconnaissance mapping of northeastern Iowa; reconnaissance of southeastern United States; compilation of a general geologic map of the United States; discrimination and description of three great geologic formations of wide extent and great significance in the history of the continent; the elucidation of a considerable part of the Neozoic continental history of southeastern United States; the development of a method of geologic correlation, entitled homogeny, whereby more definite results are thought to be obtainable than in any other way; substantial contributions to the science of physiography; the approximate determination of the extent and limitations of the theory of isostasy ; contributions to knowledge of general deformation of the terrestrial crust; a study of the origin and distribution of natural gas and rock-oil; the formulation of the principles of evidence 
concerning the antiquity of man, and the proposal of a scheme of genetic taxonomy of geological phenomena.

When the subject of our sketch laid down the responsibilities of his position on the Geological Survey to go with Major Powell as chief in charge of the Bureau of American Ethnology, he merely took up vigorously another line of scientific research in which he earlier had been deeply interested, and which he had sporadically followed from time to time in spite of pressing geological duties. During the period of ten years in which he served in this eapacity his contributions to anthropology and especially to the knowledge of the American Indians were of lasting importance.

McGee's greatest work in the field of ethnology was on the little known Seri Indians of Tiburon island, ${ }^{4}$ in the Gulf of California, which was also one of his first official investigations. Soon, however, owing to the failing health of his superior, the administrative duties rapidly became more and more burdensome, so that he found little time to devote to field studies. During the last two or three years of his connection with the Ethnological Bureau he was completely occupied in the supervision of the work of others.

When the World's Fair at St. Louis was established, in 1903, to commemorate the Louisiana Purchase, Doctor MeGee was appointed Chief of the Department of Anthropology. As in all he undertook he at once brought into play his tremendous stores of energy. The huge and varied assemblages of the peoples of the earth that he brought together amply attest the unprecedented success of his efforts. At the close of the exposition St. Louis chose him to organize the vast, new Public Museum, a labor involving extraordinary endurance, foresight and planning, since the nucleus of this great undertaking consisted of the exhibits aequired from the Fair. As it were, a Noachian flood of materials required immediate attention and installment. The usual work of many years had to be accomplished in a few weeks and months. MeGee rose to the oceasion.

417th Report Bureau of Ethnology, 1896, pt. I, p. 1-344. 
The great and novel achievement of a vast public museum in a large city created in a day instead of developed through a century, being accomplished satisfactorily, the director resigned his arduous post to accept one scarcely less arduous. He was appointed by President Roosevelt as a member of the Inland Waters Commission. The work of this organization and that of the Hydrographic Division of the Agricultural Department at Washington occupied the undivided attention of MeGee until a short time before his "demise.

In $1888 \mathrm{McGee}$ was united in marriage to Miss Anita Newcomb, daughter of Professor Simon Neweomb, the astronomer. Mrs. MeGee is a mathematician of more than national reputation and a physician in Washington. The honeymoon was a novelty, being converted into a geological exploration. Starting in Florida in early summer the pair traversed Georgia, Alabama, Mississippi, Tennessee, Kentucky and Illinois, reaching Iowa three months later. The entire trip was made on horseback, tracing the Columbia and Lafayette terranes.

Doctor MeGee was a voluminous and interesting writer. Besides his more comprehensive works, which eomprise a dozen or more large volumes, he was the author of upwards of three hundred shorter memoirs and articles. Of his larger efforts special mention should be made of the Pleistocene History of Northeastern Iowa, the Geology of Chesapeake Bay, the Lafayette Formation, Potable Waters of Eastern United States, Siouan Indians, Seri Indians and Outlines of Hydrology.

The wide scope of MeGee's intellect, the keenness of his perception and the accuracy of his reasoning can only be appreciated by direct reference to the long list of his publications. He wrote in charming style and his descriptions of some of the grander phenomena of geology often displayed a highly artistic use of language.

Time and suffering did not diminish this scientist's activity. He was vigorous to the end. He died of cancer of the stomach. A few days before his death he dictated one of the most graphic and detailed descriptions of the symptoms of the 
dreadful malady that has ever appeared in the English language. It was printed in Science shortly after his passing away. ${ }^{5}$ His heroic nature was well displayed in a letter which he wrote me a month before his demise. After fully discussing certain geologic problems in which he had been long interested he mentioned briefly his illness. He grimly closed with the remark: "I am now on my back, which looks well for the disease and bad for the man."

Doctor MeGee was a prominent member of many of the learned societies. Among other honors bestowed upon him at different times were the following: United States Commissioner of the American International Commission of Archeology; Chairman of the organizing committee for the International Geographical Congress; Senior speaker for the Department of Anthropology at the World's Congress of Arts and Sciences; Secretary of the Conference of Governors at the White House; leading founder of the Columbian Historical Society; President of the American Anthropological Association; President of the Washington Anthropological Society; Acting President of the American Association for the Advancement of Science; President of the National Geographical Society, and Secretary and Vice President of the Archeological Institute of America. Cornell College in 1901 conferred upon him the honorary degree of LL. D.

In later life Doctor MeGee presented a very distinguished, almost picturesque, appearance. In conversation he was fascinating because of his ever keen interest in the subjects under discussion. He was a past master in lecturing and especially in delivering in abstract the substance of technical papers. Grace, directness and lucidity marked these oceasions. Stalwart, versatile, tireless, brave and gentle to the last was our departed friend. As Doctor Hovey, the eminent secretary of the Geological Society of America, wrote me a few days after the demise: "Doctor McGee was a man of tremendous energy, wide reading and observation, clear thinking and good writing, so that he will be greatly missed from the ranks of geologists."

5Seience, v. 36, September 13, 1912. 
To one familiar with the ground covered by MeGee's recorded work, it is quite manifest that he was not only a brilliant thinker, but also an original reasoner. His various speculations on glacial geology, on homogenic correlation of geologic terranes, and on the origin of desert plains were no doubt founded on a large amount of original research in the field and on the skilful use of the results of others. Yet a careful review of his incessant efforts shows that they were of the old reconnaissant type such as characterized his earlier investigations in northeastern Iowa. There is a clear lack of detailed and critical inquiry which is so essential in the formulation of hypotheses and in the rigid testing of them step by step. By this deficiency he was severely limited, and his later work was partly circumseribed by the conceptions and methods of his early results. This tendency is well illustrated in his glacial labors and in his observations on the development of desert landscapes. Ten years before any suggestion was even made he had discovered and published all the facts which supported the tenet of the complexity of the glacial period. He was the first to offer a plausible explanation for the existence of the remarkable rock-floors of the arid plains, but he aseribed the phenomenon to floodsheet erosion when the erosive effects by water were almost nil. In both cases he misinterpreted the testimony presented and thus he came within a hair's breadth of making two of the half dozen great geologic discoveries of the nineteenth century. On the whole, and especially on the suggestive side of American geology, McGee's scientific work will rank high.

We stop the press to announce a difficulty between the Sacs and Winebagoes. It appears that the Foxes and Winebagoes had agreed to hunt on the same ground during the fall and winter, some 50 or 60 miles west of DuBuque, on the heads of the Waubesepinacon river. Two or three days after, a party of Sacs, headed by Pashapahoo, or Stabbing Chief, attacked the Winebagoes and killed 40 or 50. Two of the Sacs were killed.

-Iowa Sun, Davenport, November 13, 1839. 
Copyright of Annals of Iowa is the property of State of Iowa, by \& through the State Historical Society of Iowa and its content may not be copied or emailed to multiple sites or posted to a listserv without the copyright holder's express written permission. However, users may print, download, or email articles for individual use. 